\title{
A Spatial Analysis Approach to Understanding Caddoan Mounds in the Arkansas River Drainage
}

Gregory Vogel

Unknown

Follow this and additional works at: https://scholarworks.sfasu.edu/ita

Part of the American Material Culture Commons, Archaeological Anthropology Commons, Environmental Studies Commons, Other American Studies Commons, Other Arts and Humanities Commons, Other History of Art, Architecture, and Archaeology Commons, and the United States History Commons

Tell us how this article helped you.

This Article is brought to you for free and open access by the Center for Regional Heritage Research at SFA ScholarWorks. It has been accepted for inclusion in Index of Texas Archaeology: Open Access Gray Literature from the Lone Star State by an authorized editor of SFA ScholarWorks. For more information, please contact cdsscholarworks@sfasu.edu. 
A Spatial Analysis Approach to Understanding Caddoan Mounds in the Arkansas River Drainage

\section{Creative Commons License}

(c) (i) \&

This work is licensed under a Creative Commons Attribution-NonCommercial 4.0 International License 


\title{
A Spatial Analysis Approach to Understanding Caddoan Mounds in the Arkansas River Drainage
}

\author{
Gregory Vogel
}

\section{Introduction}

In this article I present a theoretical framework for understanding Caddoan mounds in the central Arkansas River drainage and the implications they may hold for the social structure and environmental adaptations of the people who made them. The power and efficiency of Geographic Information Systems (GIS) modeling now allows for large-scale, computationally intensive spatial analysis simply not possible before. Questions of landscape organization or spatial relationships that previously would have taken months or even years to answer can now be solved in a matter of minutes with GIS and related technologies, given the appropriate datasets. Quite importantly, though, such analyses must first be placed in context and theory if they are to be meaningful additions to our understanding of the past.

While it is conventional to refer to "GIS analysis" (and I use the term in this article), it is important to keep in mind that data manipulations alone are not analysis. GIS, along with statistical software and related computer technologies, are tools of spatial analysis just as shovels and trowels are tools of excavation. Such tools can organize and reveal information if they are employed carefully, but the tools themselves have no agency and cannot interpret anything on their own. The terms "GIS analysis" or "GIS interpretation" are therefore somewhat misnomers, just as "trowel analysis" or "trowel interpretation" would be. It is not the GIS, or any component of it, that does the analysis or interpretation; it simply manipulates spatial data. We interpret these manipulations based upon theoretical background, previous research, and the questions we wish to answer.

My goal in this article is to present one theoretical framework for understanding mounds in the central Arkansas River drainage, using analyses based in GIS manipulations of spatial data. The specific analyses proposed here are not complete, and it is not my intention to try to impose this model on all spatial analysis of mounds in this region or elsewhere. I hope to present this framework as an example of how such studies may be grounded, taking into account existing theories and methodologies. While it is clearly not appropriate for all studies of Caddoan mounds, this framework may serve as a springboard for other, related lines of inquiry.

Mississippian period mounds occur throughout the southeastern United States, and while those in the Arkansas River drainage of eastern Oklahoma, western Arkansas, and southwestern Missouri have received comparatively little attention, they represent a rich and unique archeological resource that surely holds a great deal of information. From about A.D. 900 to 1400 populations in this area constructed massive earthworks that clearly required the sustained effort of large groups of people to complete. Some of the earthworks served as burial mounds, some covered the remains of what appear to be structures for processing the bodies of the deceased, and others served as platforms for buildings, enormous fires, and ceremonies involving periodic excavation and re-working of large portions of the mound. A single one of these mounds along the Arkansas River (Craig Mound at the Spiro site) produced the majority of Southeastern Ceremonial Complex artifacts found to date. How these mounds relate to the natural environment and to the political and subsistence systems of the people who built them; why they are located where they are; and why some are much larger than others is still little understood. I propose the use of spatial analy- 
sis through GIS to assess the influences of arable bottomland, viewsheds, landforms, river travel routes, and the positions of other mounds on the location, patterning, and size of these monuments in order to better understand their meaning and the structure of the societies who built them. In other words: what accounts for the size and locational characteristics of the mounds? With this information, I propose that four specific hypotheses concerning the mounds can be tested: (1) they reflect the location and relative size of locally autonomous communities, who were primarily dependent upon locally available resources; (2) they represent administrative nodes in a regionally integrated system and their size and elaboration reflect their level within the system hierarchy; (3) they represent entrepots in a large-scale trading system; and (4) The location of mounds is patterned most directly not by political or environmental dictates, but by concerns of landscape position, viewsheds, or other matters of ritual or ceremonial importance.

The first two are competing hypotheses. The second two have implications that bear on the first two questions, but are not necessarily exclusive of each other or the first two.

\section{Archeological Background of Mounds in the Arkansas River Drainage}

Late prehistoric mound-building cultures in the central Arkansas River drainage (Figure 1) have conventionally been referred to as "Caddoan", although their cultural and genetic relation-

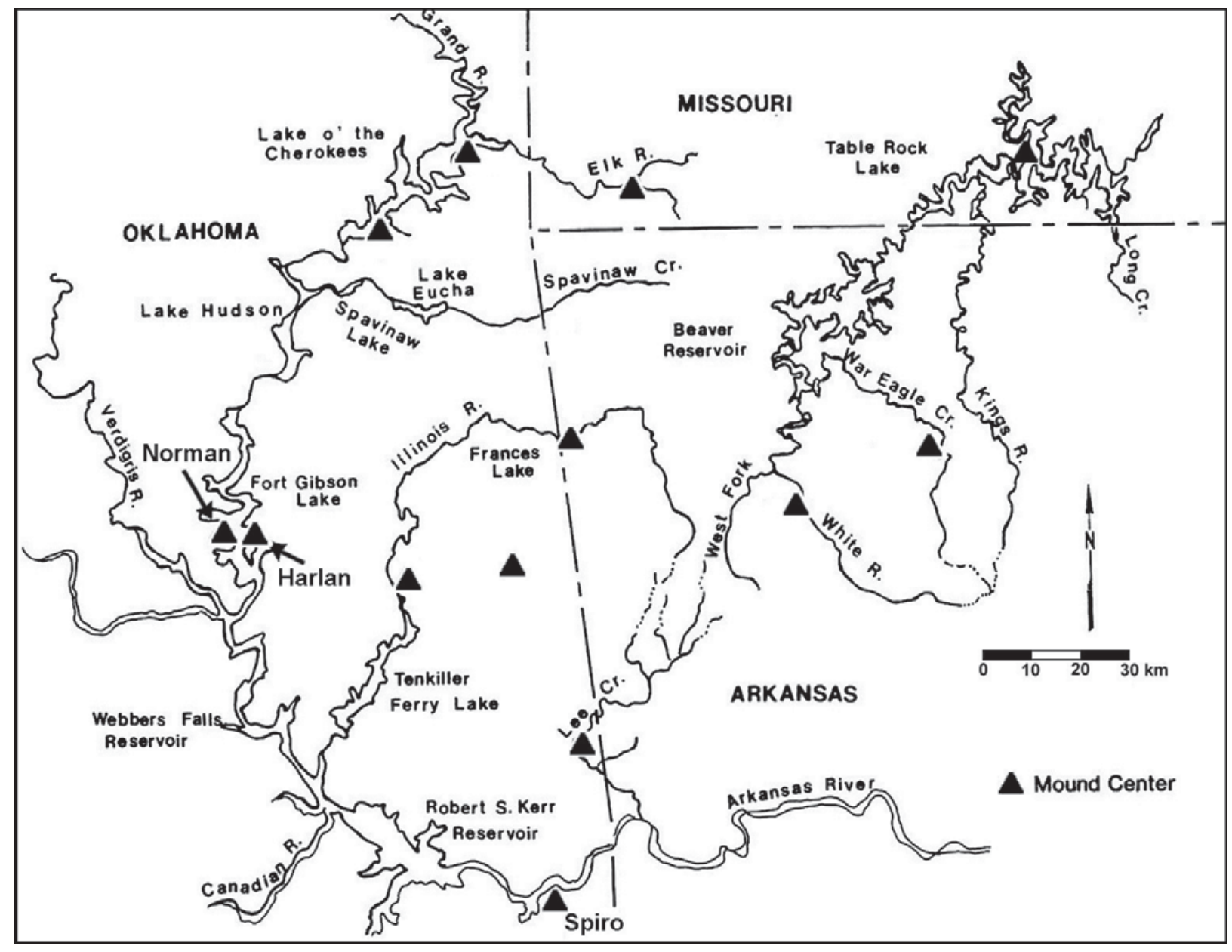

Figure 1. The location of some of the largest mound centers in the central Arkansas and upper White River drainages (Figure adapted from Kay et al. 1989) 
ship to the historically documented and current Caddo Indians is unknown. Also unknown is their cultural and genetic relationship to late prehistoric groups in the Red River valley of southeastern Oklahoma and southwestern Arkansas (the "core" Caddoan area [Perttula 1996]). Brown et al. (1978) recognize three distinct types of Mississippian mounds within the region: structure mounds (which bury the remains of ritually burned structures), accretional burial mounds, and platform mounds.

Structural mounds are low, conical features erected over a previously existing structure. The structures buried at the base of the mounds appear to have been used for specialized, ceremonial purposes. Many are hypothesized to have served as charnel houses or temporary burial locations. These mounds were usually constructed in a single episode, and contain few or no burials or artifacts. Structural mounds are by far the most common type throughout the Arkansas drainage.

Accretional burial mounds are elongated, multi-lobed, or round features that are the result of multiple episodes of mound building. Each building episode generally contains multiple burials, many of them secondary burials that were probably processed in the structures underlying structural mounds. Grave goods and wooden burial vaults are common features in this type of mound. Accretional burial mounds and structural mounds likely represent a basic "pair" of earthworks - structural mounds built over short-term processing structures, and accretional burial mounds built as permanent burial platforms for the remains. Each accretional burial mound stage may correspond to a single burial processing structure, although this has not been determined conclusively.

Platform mounds are the largest earthen structures in the Arkansas River drainage. They are generally large, round or rectangular flat-topped structures. They generally contain no burials, and the fill is commonly found to be devoid of artifacts. Mound I- 1 at the Norman site (Vogel 2001) is typical of such platform mounds, and reveals an internal structure sequence typical of that reconstructed from other platform mounds: first a mound stage consisting of a few decimeters of soil with a flat surface was constructed, then numerous large pits were excavated into this stage, exposed for an unknown amount of time, and refilled. The initial soils used for each mound stage and the soils used to refill pits appear to have come from many different sources - some of them probably local, and some of them perhaps from far away. Each mound stage was eventually capped by a compacted and burned layer of clay, and another cycle of construction commenced. Subsequent pits in higher mound surfaces never penetrate previous capping layers. Evidence for mounded berms, large posts, and other structures exists within many of these platform mounds as well, but the basic unit of construction seems to be a cyclical sequence of filling, pitting, and capping.

Sites consisting of several mounds in close association are termed civic ceremonial centers. These are interpreted as locations where important seasonal rituals took place, and as the gathering places for the expression of religious ideas and/or political power (Bell 1984; Knight 1986). Brown et al. (1978) recognize a hierarchy of civic ceremonial centers, termed first, second, and third echelon. First echelon centers contain at least one burial mound and an associated structural mound. Second echelon centers contain several structural mounds, at least one accretional burial mound, and an additional platform mound. Third echelon centers are essentially large second echelon centers with the addition of a fourth mound type or other large architectural element.

The additional mound type or architectural element is generally unique to the center, suggesting an "organizational discontinuity with the lower-order centers" (Brown et al. 1978:189). The unique structures often contain burials with large associated caches of finely made artifacts, and likely served as a burial place for regional elite. Numerous first and second echelon centers exist within the study area. Three centers are clearly third echelon centers in this region: Harlan, Norman, and Spiro (Figure 1), of which Spiro is considered the "premier" center. All mound centers in the study area are located on river floodplains or terraces, with only a few isolated mounds found in the uplands. 


\section{Theoretical Framework}

In order to reconstruct aspects of the political and social organization of the populations who constructed the mounds, I propose focusing on how the mounds are situated in relation to the natural environment, how the mounds are situated in relation to one another, and how the distribution and patterning of mounds changed through time.

The mound centers are viewed by some researchers as individual nodes in regionally integrated political systems, while others view each mound center as comprising an essentially complete and autonomous political unit. These views are well articulated in recent volumes by Muller (1997) and Emerson (1997), who propose competing models of Mississippian political organization, both of which incorporate the place of the mound centers themselves within Mississippian society. Muller (1997) has argued strongly that mound centers, in at least some locations, represent autonomous units, and Emerson (1997) has argued equally strongly that in many locations each mound center is part of a larger hierarchically organized system. Both hypotheses have implications that are testable through spatial analysis.

Muller (1997) argues that no true social ranking was necessary for the construction of mound centers. In this interpretation, local communities were autonomous agricultural units who may have affiliated with the larger mound centers, but maintained smaller mound centers as markers of, and possibly necessary constructions for, their own autonomy. The surplus necessary for the small and large centers was generated locally in this model, and the size of mound centers conditioned by the locally available resources.

Emerson (1997) takes a nearly opposite view, arguing for strong control by elite populations who extracted tribute through a hierarchical system of government reflected in the relationships of the mound centers. In this interpretation, mound centers served as both markers of control and outposts of elite authority, possibly the very locations of tribute or tax collection. The surplus necessary for the small centers was regionally integrated in this model, derived from the surplus generated within the territory of the large mound centers, and redistributed from a central source.

Neither Emerson's nor Muller's views were developed as pan-Mississippian models of political organization, but both models have testable implications for the distribution and patterning of mounds within the central Arkansas drainage. Muller's autonomy model implies a more

direct correlation between locally available resources and mound center preeminence and size. If construction of the mound centers relied chiefly on surplus generated locally, their size and elaboration should reflect available bottomland within the territory of the mound centers. The distribution of mounds within the bottomlands, and some measure of the territorial resources represented by each, would approximate the hypothetical distribution of mounds in Figure 2a. This distribution reflects sub-sets of the population who may have had close ties to neighboring groups, but maintained a large degree of political independence reflected in an investment of local resources into local monumental architecture. Graphing mound center size against locally available bottomland would approximate the scatter plot in Figure $3 \mathrm{a}$.

Emerson's hierarchy model implies a non-direct relationship between locally available resources and mound center preeminence and size. Kay et al. (1989) similarly interpret the patterning of the mound centers in the Arkansas and White River drainages as reflecting a well organized, widespread settlement system. They note the nearly regular spacing of some of the larger mound centers, and of the interspersed smaller "satellite" centers (Figure 4). This interpretation corresponds closely to Emerson's view of a highly structured, hierarchical system of populations represented by large mound centers exacting tax or tribute from populations at smaller mound centers. The distribution of mounds within the bottomlands, and some measure of the territories 

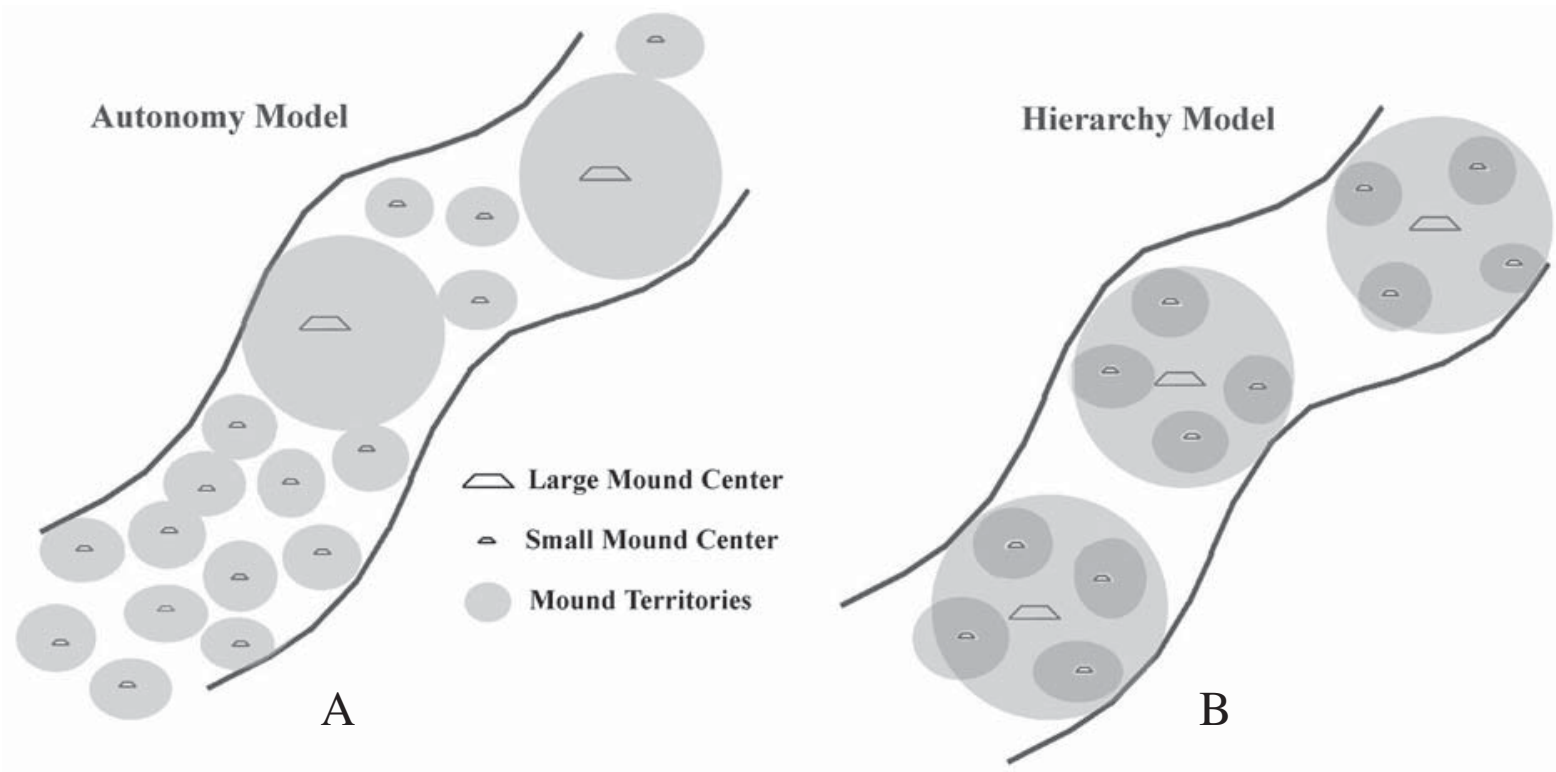

Figure 2. Idealized mound distributions. Left represents the model proposed by Muller (1997) of largely autonomous mound centers whose size and elaboration depended primarily on locally available resources. Right represents the model proposed by Emerson (1997) of hierarchically-organized mound centers, with larger centers extracting resources from smaller ones.

represented by each, would in this case approximate the hypothetical distribution of mounds in Figure $2 \mathrm{~b}$. This distribution reflects the necessity of not simply larger tracts of arable bottomland within the territories of the larger centers, but the necessity of a certain number of associated smaller mound centers.

The scatter plot in Figure 3b approximates the mound center size to territory size relationship that would exist if this model is correct. Note that the variable of territory size in this analysis is not a direct measure of land area, but a measure of the agricultural and biological productivity of that area.

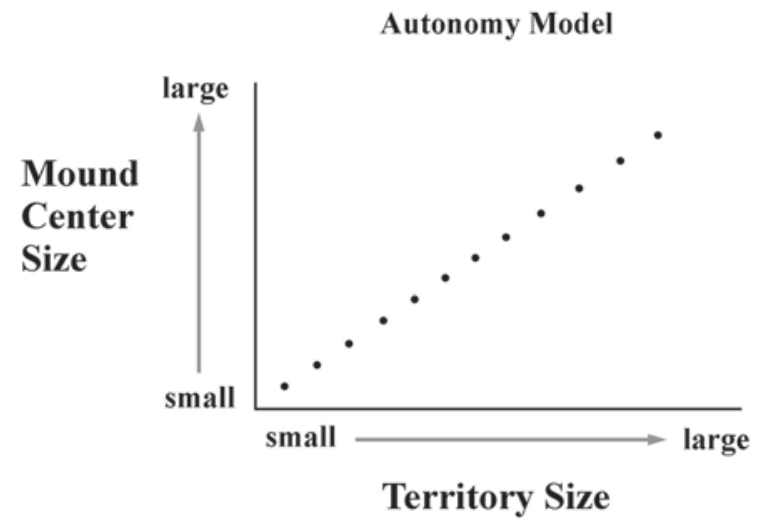

A
Hierarchy Model

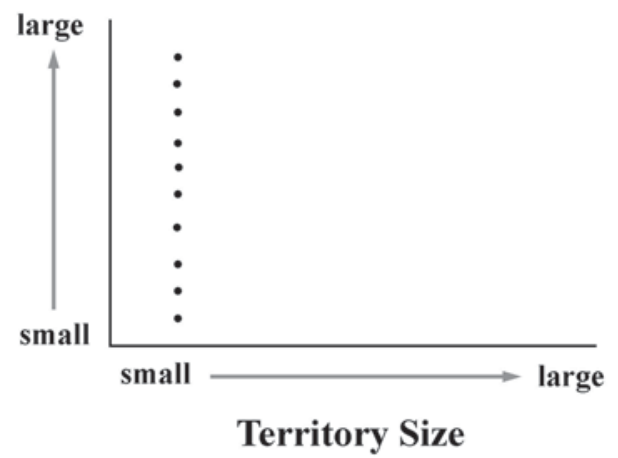

$\mathrm{B}$

Figure 3. Idealized graphs of mound size and territory relationships. The autonomy model corresponds to Muller's (1997) view of mound centers as autonomous centers relying on locally available resources. The Hierarchy model corresponds to Emerson's (1997) view of mound centers as hierarchically organized units with larger centers extracting resources from smaller ones. Note that the variable of "Territory Size" takes into account the availability of resources within the territory. 


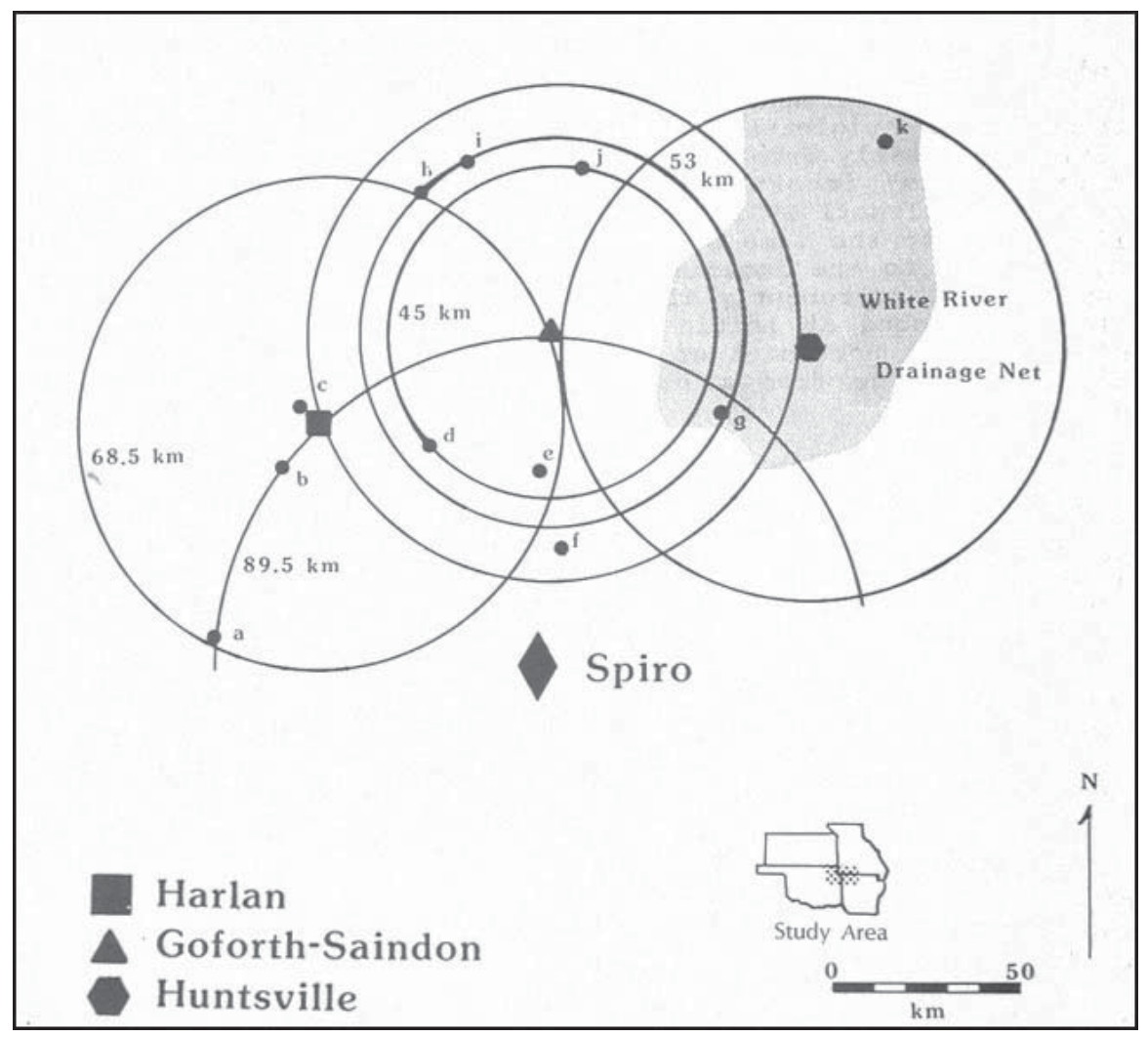

Figure 4. Distances between large and small mound centers (from Kay et al. 1989).

The Spiro site has long been recognized as a potential "gateway" trading community, situated between the plains to the west and north, and eastern woodlands and Mississippi River bottomlands to the east. Spiro's location along a major waterway connecting these regions (the Arkansas River) is often cited in support of its importance as a trading center, and the vast quantity of high-status, exotic items found at Spiro certainly point to the importance of long-distance trade in at least these items. Schambach (1999) argues that trade at the Spiro site and elsewhere in the Arkansas River drainage extended far beyond high-status, exotic goods, serving as an important economic input for the community. In this interpretation, Spiro gained preeminence in the region not directly because of locally or regionally generated agricultural surplus, but because of control over long-distance trade. If this were the case, the mound center locations may reflect waterway trade routes rather than prime agricultural lands.

Note that the "trade hypothesis" is not mutually exclusive of the hierarchy model, and may not be exclusive of the autonomy model. What spatial analysis will be able to determine is the relative strength of each model, based on the location and patterning of the mound centers across the landscape. Isolated mound centers, each within an exclusive area of bottomland resources corresponding to the size and elaboration of the mound center, would support the autonomy model. A highly organized system of mound centers, with the larger centers surrounded not by more abundant bottomland, but by numerous smaller centers, would support the hierarchy model regardless of the importance of trade.

Another possibility is that the locations of the mound centers are patterned most directly not by environmental or political concerns, but by some aspect of cosmology or ceremony related to the meaning of the mounds as ritual monuments. While all such factors may not be detectable in the location or patterning of the mounds, one such concern that is testable is the viewsheds of the mound centers - the extent of area visible from the centers- and the area from which the 
mound centers themselves are visible. Bradley (2000) and Gaffney (2000) have both demonstrated viewshed considerations are important in the placement of Old World monumental architecture. Sabo (personal communication) has noted that several area mound centers appear to be situated in "natural amphitheaters" within the river valleys; that is, preferentially located in areas with large viewsheds. If this is the case, other location considerations based on political organization or the distribution of environmental resources may be partly or completely obscured. Just how obscured the other influences would be depends on how important viewsheds were to mound locations.

Addressing these questions will first require determining the relative importance of landforms, locally available arable land, river travel networks, the locations of other mound centers, and viewsheds to mound patterning, size, and location through time. If locally available arable bottomland were shown to be the primary factor controlling mound center size, it would lend strength to the autonomy model. If the location of other mound centers were shown to be of prime importance, the hierarchy model would be greatly supported. If the size and elaboration of mound centers is more directly correlated with ease of travel between key trading resources, the trading hypothesis would be supported. If viewsheds turn out to be quite important to mound locations, it would demonstrate the greater influence of ceremonial or cosmological considerations over political or environmental ones in the locations of mound centers. If none of these factors were found to be significant, it may force us to reconsider the commonly held assumption that the locations of the mounds are intimately related to and reflect the political or subsistence systems responsible for their creation.

\section{GIS models and data needs}

The scope and depth of the spatial analyses I propose will only be possible through the power and efficiency of Geographic Information Systems (GIS) technology. Such analyses should expand and elaborate on previous studies conducted within the study area and elsewhere, and offer new lines of research simply not possible before GIS. Two separate datasets could be employed, one pertaining to the natural landforms and environment of the study area, the other pertaining to the mound centers themselves. Information pertaining to the location, size, use, construction, and abandonment of the mound centers is largely available in the published literature and from archeological field notes and other unpublished sources.

Little reliable documentation exists concerning several of the mound centers, however, particularly the ones which were partially or completely destroyed or inundated during river impoundments or other construction. Cavanaugh Mounds site in Fort Smith, Arkansas, for example, now consists of only a portion of a single large mound. A partial profile is exposed along the eastern side of the mound, and loading features of highly contrasting matrix, typical of area platform mounds, have been reported by Arkansas Archeological Survey personnel who have visited the site. The loading features and size of the mound suggests that other mounds were once present at the site, but no formal archeological research has been conducted in the surrounding area. Still, early narrative records or photographs will likely offer enough information for a ranking of the site within Brown et al's (1978) echelon system.

A basic chronological framework has been constructed for the area (most recently in Brown and Rogers [1999]), but placing many of the smaller mound centers in time is still a difficult task. Datable material exists for many of the mound sites, however, even those that were destroyed by construction of the river navigation system. Diagnostic lithic and ceramic artifacts and organic material suitable for AMS radiocarbon dating may help in this regard. Understanding the timing of mound use and construction is essential for many of the analyses proposed here, in particular those that evaluate the mound centers in relation to one another as well as the environmental background. 
Historic aerial photographs are a particularly promising source of information concerning the mounds. The U.S. Department of Agriculture commissioned aerial photographs in the 1940s and 1950s that cover the entire study area (now curated at the National Archives in Washington D.C.). These photographs were taken prior to the inundation of the reservoirs, and prior to much of the large-scale construction and development that cover much of the area today. The photographs were mostly taken in the late winter and early spring, and contain enough detail to resolve features less than one meter on a side. Naturally formed prairie mounds, for example, far smaller than the culturally constructed mounds in the study area, are clearly visible in one of these photographs from Pea Ridge National Park within the study area. These photographs thus appear to be a largely untapped resource for mound studies, and I anticipate they could be quite useful in determining the layout of mound centers for those that were never mapped, and for confirming or revising the exact position and layout of those that have.

The environmental layers of the GIS model should be based on the pre-reservoir topography of the study area. U.S.G.S. 30 meter digital elevation models (DEMs) should serve for the upland portions of the study area. The overall topography of the uplands has changed little throughout the Late Holocene, and current elevations accurately reflect the Late Mississippian landscape, above the major river valleys.

Much of the area bottomland is now underwater as part of the McClellan Kerr River Navigation System, administered by the Tulsa District U.S. Army Corps of Engineers. Several different sources could be used to reconstruct the pre-reservoir topography and hydrology of these inundated bottomlands. The Tulsa District U.S. Army Corps of Engineers possesses topographic maps (in paper form only) of much of the area before inundation, and bathymetric data for all of the reservoirs shortly after their inundation. General Land Office and other early maps may be useful in reconstructing much of the hydrology, as well as other aspects of the natural environment (backwater lakes that may now be drained, for example).

As with the locations and layouts of the mound centers themselves, early aerial photographs appear to be a largely untapped resource for hydrological and environmental reconstruction in this area. River courses, floodplains, terraces, backwater lakes, and valley edges are clearly visible in these photographs, mostly taken prior to inundation of the reservoirs. Variations in texture and value in the photographs also express differences in soil and vegetation, which would likely be quite useful in understanding potential environmental resources in different parts of the study area bottomlands.

\section{Specific analyses and potential outcomes}

Figure 5 outlines the main components of the proposed research in a flow chart, detailed in the paragraphs below. As with most GIS-based projects, the majority of the effort would be dedicated to simply working the information into a usable format. The quality of the analysis is conditioned by the quality of the GIS model. Incorporating numerous sources (existing digital elevation models, early paper maps and aerial photographs, etc.) would ensure that the model is as accurate as possible. The actual manipulations performed on the dataset must be carefully chosen for appropriateness, but require comparatively less time and effort.

The great majority of individual mounds and all mound centers within the study area are located in stream valleys, below the uplands. It is clear that their locations across the landscape are not at all random, but highly patterned by at least this one environmental variable. A preliminary step in the analysis would be to determine the relative influence of all reconstructed natural landscape types and features on the locations of the mound centers within the river valleys. For example, are more of them located on first or second order terraces than would be expected by chance, or are 


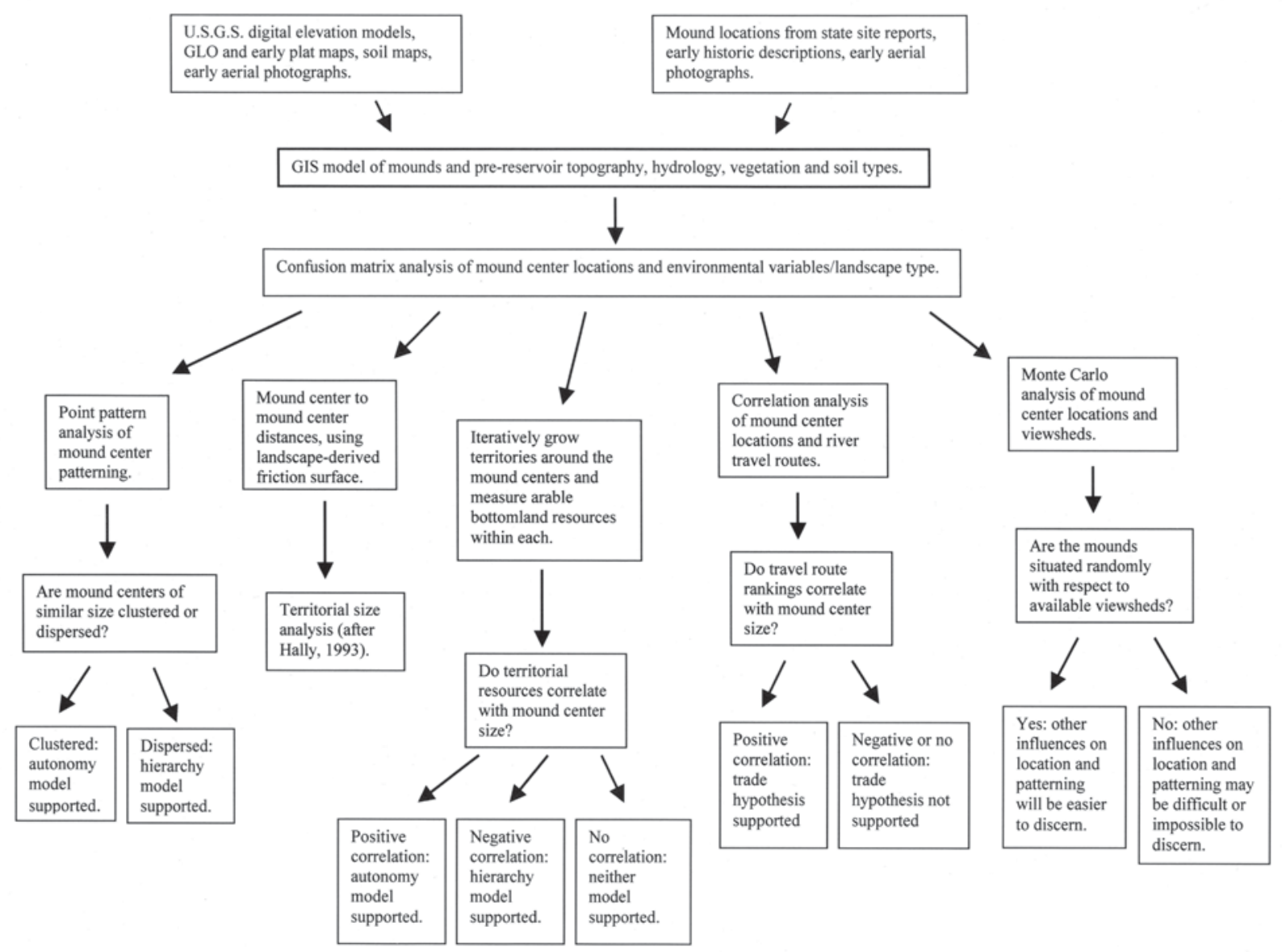

Figure 5. Flowchart of proposed analyses showing basic GIS steps and some of their analytical implications.

they closer to or farther from river channels? These analyses are easily conducted through GIS as spatially derived chi-square tests, termed "confusion matrices" in GIS terminology. The amount of area covered by any landscape type or environmental feature is quantified in this analysis, and the expected versus observed occurrence of mounds on the area is determined. Standard statistical procedures determine the significance of any discrepancies. This information could serve as the statistical background for subsequent analyses, and may in itself reveal interesting or important patterns.

\section{Point Pattern Analysis}

At a landscape scale, mounds and even mound centers can appropriately be considered one-dimensional points, and simply applying conventional point-pattern analysis techniques holds promise. Boots and Getis (1988) detail various measures of point pattern arrangement and dispersion that may prove useful. These measures reveal how clustered, how dispersed, or how randomly arranged any series of points are. These analyses are conducted without consideration of the background environment, but within a GIS model various background variables are easily taken into account.

Two specific analyses could be used to analyze the mound center point patterns: variance to mean ratio, and autocorrelation. Variance to mean ratio is a measure of point clustering or dispersion based on point counts within assigned quadrats. In this case, the quadrats will be defined by the bottomland landforms on which the mounds are located. A variance to mean ratio near 1 
indicates randomness, while a ratio significantly greater than 1 indicates clustering of the points, and significantly less than 1 indicates dispersion.

Determination of spatial autocorrelation compares the actual occurrence of points per cell (again defined by the landforms on which the mounds are located) to a random distribution. A statistic near 0 signifies randomness in the points, while lower values indicate dispersion and higher values indicate clustering, or regional trends of similarity in the data (a statistic of -1 indicating perfect dispersion and +1 indicating perfect clustering).

Aside from their utility as exploratory statistics in understanding the layout of the mound centers across the landscape, these methods have the potential to confirm implications of the autonomy and hierarchy models. Because the large mound centers in this model are centers of control over smaller centers, they should not be clustered but should have a "repelling" effect on one another, particularly taking into account available resources. Kay et al. (1989) interpreted the nearly equal spacing of larger mound centers within the Arkansas and White River drainages as evidence of regional organization (see Figure 4). GIS spatial autocorrelation analysis, conducted on selected sets of mounds (grouped by a measure of mound center size, such as Brown et al's [1978] hierarchy system), could be used to refine this type of analysis by taking into account the landscape against which the mounds are set, and to quantify the results. If the larger mound centers are significantly dispersed, the hierarchy model would be supported. If they are significantly clustered (that is, the larger centers are closer to one another, on average, than they are to the smaller centers), the autonomy model would be supported: particularly if the larger centers also happen to be located within the largest stretches of arable bottomland.

\section{Mound center to mound center distances}

Mississippian mound center territories in northern Georgia have been estimated by Hally (1999), using distances between mound centers. Hally found a bimodal distribution of distances between contemporaneous mound centers, and concluded that those closer together represented administrative centers for single polities, while those farther from other mound centers represented "paramount chiefdoms" with direct control over multiple communities. Hally used straight-line distances between mound centers to serve as rough approximations of travel times.

A GIS-based study could conduct a similar analysis of the distances between mound centers, but with a more realistic approach than is possible without employing computer modeling. From the landscape model discussed above, it is possible to derive a landscape friction surface based upon terrain, hydrology, and other environmental variables. Friction surfaces classify the landscape based upon ease of travel. It is easier to walk over level terrain, for example, and more difficult to walk up steep slopes. People will generally walk around backwater swamps and lakes, while river routes and large lakes could clearly serve as relatively high-speed transportation routes. Various studies (e.g.,. Brannan 1992) have determined the calories necessary to travel across different terrains, and could serve to calibrate the friction surface to actual human cost.

\section{Territories derived from friction surfaces}

GIS is uniquely suited for estimating territories based on realistic landscape properties. Several estimations of territories have been used in archeological research with varying degrees of success. Simple circles drawn around sites were first used for site catchment analysis, and have recently been usefully applied to studies of Mississippian mound center territories in Georgia (Hally 1999). Based on the common-sense assumption that whatever is closer is easier to procure, such circles serve well in some cases, but do not take into account the environmental background against which the centers are set, or the possibility of multiple territories influencing one another. 
More sophisticated are Thiessen polygons (also known as Voroni tessellations), which divide landscapes around designated points in a more realistic manner. Thiessen polygons include within the territory of each point all area that is closer to it than to any other point. Territorial approximations derived in this way have been usefully applied in many archeological studies, even revealing distinct Mississippian settlement patterns (e.g., Muller 1997). This type of analysis assumes an equal value for all points, however, and again fails to take into account the background variables against which the points are set.

Using friction surfaces derived from topographic and environmental variables (as discussed above), it is possible to "grow" territories from each mound center through iterated operations that take into account the ease of travel across the landscape. Thus territories for mound centers in narrow, deep valleys with rough adjacent uplands will spread preferentially along the bottomland where travel is easier. The landscape can be completely tessellated in this way so that no land remains outside of a territory, or the territories can be successively shrunk back to take into account different potential buffer zones between territories.

Topographic, hydrologic, and soils data could be used to rank area bottomlands for suitability for prehistoric agriculture. In general, organic-rich bottomland soils that flood infrequently are the most suited to prehistoric agriculture. In the study area, these are primarily on natural floodplain levees and low terraces without backwater lakes.

The landscape could then be tessellated with several variations of mound center territories, using territorial approximations derived from mound center distances as well as variations that take into account the potential for greater territories for larger mound centers. The resources within each territory could be quantified (amount of arable bottomland likely to flood no more than once per season, etc.) and tested first against a random distribution to check for statistical randomness, and then against mound center size as illustrated in Figures 2 and 3. This analysis has the potential to support or contest the autonomy and hierarchy models.

\section{River travel route analysis}

Surfaces from each mound center could be created in a manner similar to the generation of territories, with a polygon expanding from the mound center along a friction surface derived from the landscape and hydrological information. In this analysis, the "territories" would be expanded from each mound center to cover the entire region. Each pixel (30x30 meters) could be coded with a travel value corresponding to the cost in calories to reach it from the mound center.

Mound centers situated at the nexus of major stream branches will have larger areas with lower travel values in this analysis, indicating ease of travel to and from these sites. Mound centers located at the headwaters of streams or along low-order tributaries with no nearby branch streams will have very small areas with low travel values, indicating relatively difficult travel to and from these sites. It would then be possible to create an ease-of-travel index using a ratio of the area covered divided by the cumulative travel value for that area. A ranking of the mound centers (again using Brown et al.'s [1978] echelon system as a first approximation) could then be correlated with the index. If ease of travel over large areas was an important factor for locating the mound centers in the first place or for the elaboration of the mound centers even after they were founded, the correlation should be high. If this correlation were extremely high (that is, the size and elaboration of the mound centers correlates quite strongly with the location's access to travel routes), the autonomy and hierarchy models may not be testable, with the influence of locally or regionally available resources obscured by the importance of river travel routes. 


\section{Viewshed analysis}

Viewsheds may be an important factor in mound center locations, and if this is the case, other influences on mound center location may be partly or completely obscured. Many of the mound centers appear to have commanding views up and down the river valleys, but how many sites with such views should we expect by chance, and given the landscape of the region, what exactly should we consider a "commanding" view? GIS "Monte Carlo" analysis could be used to test for the importance of viewsheds in the positioning of mound centers.

A set of observations is randomly generated in this type of analysis, within realistic parameters drawn from observation. For example, several thousand sets of mound centers could be randomly generated across the landscape model, using parameters drawn from confusion matrix analysis of the actual mound centers to ensure that the same proportion of them are on similar landforms, soil types, similar distances from river channels, and any other variable that needs to be held constant. The generated samples represent a statistical background against which to test the actual mound locations. Standard statistical procedures can be used to compare the observed and generated datasets, as appropriate. If the mound centers, or any selected subsets (third echelon centers, for example) were found to be significantly different from the randomly generated sets, viewsheds would be considered a significant contributing factor to mound center locations. This type of analysis assumes no statistical normality to the data, and is useful when population parameters are difficult to discern or quantify (Kvamme 1999), which is clearly the case with the viewsheds of the mound centers.

Aside from the viewsheds of individual mounds, studies of overlapping viewsheds and multiple viewsheds have proven useful in archeological applications (Gaffney and van Leusen 1995; Ruggles et al. 1993). Multiple viewsheds are formed by the overlap between individual viewsheds on a landscape, representing areas visible from multiple points of interest. Cumulative viewsheds rank the landscape by the number of points of interest from which an area is visible. Kvamme notes that these types of analyses have been used "as a means to perceive past social or cognitive landscapes, and even territoriality" (1999:177). While the distances between the majority of the larger mound centers are likely too great to allow for any intervisibility, there may be some overlap or even chains of connection between the viewsheds of the smaller, more numerous mound centers. These could possibly point to culturally important locations on the landscape even where little or no physical evidence exists.

\section{Conclusions}

In this articleI have attempted to outline how GIS-based spatial analysis may help us understand something of the political organization and environmental adaptations of Mississippian mound builders in the central Arkansas River drainage. Such analysis has the potential not only to refine and quantify previous research (e.g., Hally 1999; Kay et al. 1989; Muller 1997; Wyckoff 1980), but also to broaden the scope and extend the lines of inquiry in novel directions. I have proposed doing this by integrating data concerning the mounds themselves with environmental information at a regional scale. Studies of this scale and computational complexity have only been made possible by recent advances in GIS and related technologies. It is now possible to reconstruct fine-scale environmental and landform information, determine the relative influence of these variables on the position and elaboration of mound centers, and use the resulting information to directly test some of the implications of various hypotheses concerning the mounds. 
This article is not simply an academic exercise. I am currently preparing the GIS model and beginning to conduct many of the analyses outlined here. I hope to present the results of these analyses in Caddoan Archeology Journal and other forums. When complete, the full database of mound, landform, and environmental information will be made available through web-based distribution. I hope this information will be useful to other researchers interested in similar questions, and will serve as a model of data sharing crucial for the advancement of such studies.

\section{Acknowledgments}

This articleis largely based on a proposal for a National Science Foundation Doctoral Dissertation Improvement Grant (funded as NSF grant number 0341068, DDI: Location and Patterning of Mississippian Mounds in the Central Arkansas River Valley, Gregory Vogel). I wish to thank my Dissertation Committee members at the University of Arkansas who offered many useful comments on earlier drafts of the proposal: Marvin Kay, Ken Kvamme, George Sabo, Margaret Guccione, and John Dixon. Frank Schambach and Jamie Brandon also contributed useful comments, as did four anonymous reviewers of the final NSF proposal.

\section{References Cited}

Bell, R. E.

1984 Prehistory of Oklahoma. Academic Press, Inc., New York.

Boots, B. N. and A. Getis

1988 Point pattern analysis. Sage Publications, Newbury Park.

Bradley, R.

2000 An archaeology of natural places. Routledge Press, London.

Brannan, J. A.

1992 On modeling resource transportation costs: Suggested refinements. Current Anthropology 33:56-59.

Brown, J. A., R. E. Bell, and D. G. Wyckoff

1978 Caddoan settlement patterns in the Arkansas River drainage. In Mississippian settlement patterns, edited by B. D. Smith, pp. 169-200. Academic Press, New York.

Brown, J. A. and J. D. Rogers

1999 AMS dates on artifacts of the southeastern ceremonial complex from Spiro. Southeastern Archaeology 18(2):134-141.

Emerson, T. E.

1997 Cahokia and the Archaeology of Power. University of Alabama Press, Tuscaloosa.

Gaffney, V. and P. M. Van Leusen

1996 Postscript: GIS, environmental determinism and archaeology. In Archaeology and geographical information systems: A European perspective, edited by G. Lock and Z. Stancic, pp. 367-382. Taylor and Francis, London.

Hally, D. J.

1999 The settlement pattern of Mississippian chiefdoms in northern Georgia. In Settlement pattern studies in the Americas, edited by B. R. Billman and G. M. Feinman, pp. 96-115. Smithsonian Institution Press, Washington, D.C. 
Kay, M., G. I. Sabo and R. Merletti

1989 Later prehistoric settlement patterning: A view from three Caddoan civic-ceremonial centers in northwest Arkansas. In Contributions to Spiro Archaeology: Mound Excavations and Regional Perspectives, edited by J. D. Rogers, D. G. Wyckoff, and D. A. Peterson, pp. 129158. Studies in Oklahoma's Past, Vol. 16, Oklahoma Archeological Survey, Norman.

Knight, V. J. J.

1986 The institutional organization of Mississippian religion. American Antiquity 51(4):675689.

Kvamme, K. L.

1999 Recent directions and developments in geographical information systems. Journal of Archeological Research 7(2):153-201.

Muller, J.

1997 Mississippian Political Economy. Plenum Press, New York.

Perttula, T. K.

1996 Caddoan area archaeology since 1990. Journal of Archeological Research 4(4):295-348.

Ruggles, C. L. N., D. J. Medyckyj-Scott and A. Gruffydd

1993 Multiple viewshed analysis using GIS and its archeological application: A case study in northern Mull. In Computing the past: Computer applications and quantitative methods in archaeology, edited by J. Andresen, T. Madsen and I. Scollar, pp. 125-131. Aarhus University Press, Aarhus, Denmark.

Schambach, F.

1999 Spiro and the Tunica: A new interpretation of the role of the Tunica in the culture history of the southeast and the southern plains. In Arkansas Archaeology: Essays in Honor of Dan and Phyllis Morse, edited by R. C. Mainfort and M. D. Jeter, pp. 169-224. University of Arkansas Press, Fayetteville.

Vogel, Gregory

2001 Mound I-1 Profiles at the Norman Site (34WG2). Paper presented at the combined 43rd Caddo Conference and 23rd Flint Hills Conference, Norman Oklahoma.

Wyckoff, D. G.

1980 Caddon adaptive strategies in the Arkansas basin, eastern Oklahoma. Ph.D. Dissertation, Department of Anthropology Washington State University. 